Supporting Information

\title{
Multimodal stimuli-responsive fluorophore-functionalized heterotelechelic poly(2-isopropyl-2-oxazoline)
}

Jong Min Park, Ye Ji Kim, Woo-Dong Jang*

Department of Chemistry, Yonsei University, 50 Yonsei-ro, Seodaemun-gu, 03722 Seoul, Republic of Korea

\author{
Corresponding author
}

E-mail: wdjang@yonsei.ac.kr

KEYWORDS: thermoresponsive polymer, poly(2-oxazoline), aggregation-induced emission, Förster resonance energy transfer, host-guest complex 


\section{Table of Contents}

Experimental details.

Figure S1. ${ }^{1} \mathrm{H}$ NMR spectrum of TPE-PiPrOx-Rh

Scheme S1. Synthesis of TPE-PiPrOx and R6G-PiPrOx

Figure S2. SEC trace of TPE-PiPrOx, R6G-PiPrOx and TPE-PiPrOx-R6G.

Figure S3. Absorption and emission spectra of TPE-PiPrOx and R6G-PiPrOx in $\mathrm{H}_{2} \mathrm{O}$. In the emission spectra, TPE-PiPrOx and R6G-PiPrOx were excited at 310 and $480 \mathrm{~nm}$, respectively. ... S-8

Figure S4. Emission spectra of R6G-PiPrOx in water when excited at 310 and $480 \mathrm{~nm}$ .S-9

Figure S5. Absorption and emission spectra of TPE-PiPrOx-R6G in water, excited at $310 \mathrm{~nm}$ for the emission spectrum .S-9

Figure S6. Size distributions as observed by DLS with a $1.00 \mathrm{~g} \cdot \mathrm{L}^{-1}$ solution of (a) TPE-PiPrOx and (b) R6GPiPrOx in water. .S-10

Figure S7. CMC measurements of TPE-PiPrOx and R6G-PiPrOx. (a) Plot of the FL emission intensity at 480 $\mathrm{nm}$ of TPE-PiPrOx at different concentrations $\left(2.00 \times 10^{-3}-4.00 \mathrm{~g} \cdot \mathrm{L}^{-1}\right)$ in water. (b) Plot of the intensity ratio $\left(I_{331} / I_{328}\right)$ obtained from the FL excitation spectra of pyrene $\left(2.00 \times 10^{-6} \mathrm{M}\right)$ with R6G-PiPrOx at different concentrations $\left(4.00 \times 10^{-3}-8.00 \mathrm{~g} \cdot \mathrm{L}^{-1}\right)$ in water. .S-10

Figure S8. FL emission spectrum of a 1:1 mixture solution $\left(2.00 \mathrm{~g} \cdot \mathrm{L}^{-1}\right)$ of TPE-PiPrOx and R6G-PiPrOx in water excited at $310 \mathrm{~nm}$.

Table S1. Fluorescence quantum yields of TPE-PiPrOx-R6G $\left(1 \mathrm{~g} \cdot \mathrm{L}^{-1}\right)$ with/without $\gamma$-CD $(10 \mathrm{mM})$ in water at different temperature

Figure S9. 2D NOESY ${ }^{1} \mathrm{H}$ NMR spectrum of TPE-PiPrOx-R6G $\left(5.00 \mathrm{~g} \cdot \mathrm{L}^{-1}\right)$ and $\gamma$-CD $(2.00 \mathrm{mM})$ in $\mathrm{D}_{2} \mathrm{O} . . \mathrm{S}-\mathbf{1 2}$

Figure S10. Size distribution as observed by DLS of a mixture of TPE-PiPrOx-R6G $\left(1.00 \mathrm{~g} \cdot \mathrm{L}^{-1}\right)$ and $\gamma$-CD $(10$ $\mathrm{mM}$ ) in water (inset: SEM image of the obtained micelles of the complex between TPE-PiPrOx-R6G and $\gamma$-CD. Scale bar $=200 \mathrm{~nm})$ .S-12

Figure S11. Absorption and emission spectra of $\gamma$-CD $(10 \mathrm{mM})$ in water, excited at $310 \mathrm{~nm}$ for the emission spectrum. .S-13 


\section{Experimental details}

\section{Materials and instruments}

All commercially available reagents were reagent grade and used without further purification. Acetonitrile and THF were freshly distilled before use. Recycling size exclusion chromatography (SEC) was performed on a LC9201 (JAI, Tokyo, Japan) instrument equipped with JAIGEL-1H, JAIGEL-2H, and JAIGEL-3H columns using $\mathrm{CHCl}_{3}$ as eluent. UV-Visible absorption spectra were measured using a V-660 spectrophotometer (JASCO, Tokyo, Japan) equipped with a thermostatic cell holder coupled with a controller (ETCS-761, JASCO, Tokyo, Japan). Fluorescence spectra were measured by using a JASCO FP-6300 spectrophotometer equipped with a thermostatic cell holder (ETC-273T, JASCO, Tokyo, Japan) coupled with a controller (ETC-273T, JASCO, Tokyo, Japan). The excitation wavelength for all measurements was fixed at $310 \mathrm{~nm}$. All spectral measurements were carried out using a quartz cuvette with a path length of $1 \mathrm{~cm} .{ }^{1} \mathrm{H}$ NMR, ${ }^{13} \mathrm{C}$ NMR and $2 \mathrm{D}$ NOESY ${ }^{1} \mathrm{H}$ NMR spectra were recorded with a Bruker DPX $400\left(400 \mathrm{MHz}\right.$ for ${ }^{1} \mathrm{H}$ NMR and $100 \mathrm{MHz}$ for $\left.{ }^{13} \mathrm{C} \mathrm{NMR}\right)$ spectrometer in $\mathrm{CDCl}_{3}$, $\mathrm{CD}_{2} \mathrm{Cl}_{2}$ and $\mathrm{D}_{2} \mathrm{O}$. Analytical SEC for the determination of the number average molecular weight $\left(M_{\mathrm{n}, \mathrm{SEC}}\right)$ was performed on a JASCO HPLC equipped with HF-403HQ and HF-404HQ columns (Shodex, Tokyo, Japan) and using THF as eluent. Matrix-assisted laser desorption ionization time-of-flight mass spectrometry (MALDI-TOFMS) was performed using a Bruker model LRF20 with trans-2-[3-(4-tert-butylphenyl)-2-methyl-2propenylidene]malononitrile (DCTB) as matrix and lithium trifluoroacetate or potassium iodide as salt. Dynamic light scattering (DLS) measurements were performed using an ELSZ-2000ZS instrument (Otsuka Electronics, Osaka, Japan). Scanning electron microscopy (SEM) images was obtained using 7610F-Plus (JEOL, Japan)

\section{Determination of the critical micelle concentration (CMC)}

The CMC of TPE-PiPrOx, R6G-PiPrOx, and TPE-PiPrOx-R6G was measured using a fluorescence emission spectrometer (JASCO FP-6300). The concentration of TPE-PiPrOx and TPE-PiPrOx-R6G in $\mathrm{H}_{2} \mathrm{O}$ was $2.00 \times$ $10^{-3}-4.00 \mathrm{~g} \mathrm{~L}^{-1}$ and $1.00 \times 10^{-4}-5.00 \mathrm{~g} \mathrm{~L}^{-1}$, respectively. The CMC of TPE-PiPrOx and TPE-PiPrOx-R6G was determined as the point at which the slope of the intensity at $480 \mathrm{~nm}$ changed upon excitation at $310 \mathrm{~nm}$. For the CMC measurement of R6G-PiPrOx, the concentration of the sample solutions containing $2.00 \times 10^{-6} \mathrm{M}$ of pyrene varied in the range $4.00 \times 10^{-3}-8.00 \mathrm{~g} \mathrm{~L}^{-1}$ in $\mathrm{H}_{2} \mathrm{O}$. The excitation spectra of pyrene were measured from 300 to $360 \mathrm{~nm}$ upon emission at $390 \mathrm{~nm}$. The CMC of R6G-PiPrOx was determined as the intensity ratio $\left(I_{331} / I_{328}\right)$ at 
which the slope changed.

\section{Determination of the phase transition temperature $\left(T_{C P}\right)$}

The transmittance of the solution at $800 \mathrm{~nm}$ was measured using a V-660 spectrophotometer equipped with a thermostatic cell holder coupled with a controller (ETCS-761, JASCO). The heating rate of the sample cell was adjusted to $2.0^{\circ} \mathrm{C} / \mathrm{min}$. The phase transition temperature $\left(\mathrm{T}_{\mathrm{CP}}\right)$ was determined as the temperature at which the transmittance reached $60 \%$ in the resulting transmittance versus temperature curves.

\section{Synthesis}

\section{Synthesis of compound 2}

A solution of $n$-BuLi (20.6 mL, $33.0 \mathrm{mmol}, 1.6 \mathrm{M}$ in hexane) was slowly added dropwise to a solution of diphenylmethane $(7.5 \mathrm{~g}, 44.6 \mathrm{mmol})$ in $\mathrm{THF}(100 \mathrm{~mL})$ at $0{ }^{\circ} \mathrm{C}$ under a $\mathrm{N}_{2}$ atmosphere. The mixture was stirred at $0{ }^{\circ} \mathrm{C}$ for $30 \mathrm{~min}$, and then 4-methylbenzophenone $(5.87 \mathrm{~g}, 30.0 \mathrm{mmol})$ was added. The reaction mixture was allowed to warm to $25{ }^{\circ} \mathrm{C}$ and stirred overnight. It was then quenched with $\mathrm{H}_{2} \mathrm{O}$ and further extracted with $\mathrm{CH}_{2} \mathrm{Cl}_{2}$. The organic layer was washed with brine and saturated aq. $\mathrm{NH}_{4} \mathrm{Cl}$, and then concentrated under vacuum to afford crude compound $\mathbf{1}$. Subsequently, the residue and $p$-TsOH $(215 \mathrm{mg}, 1.13 \mathrm{mmol})$ were dissolved in toluene $(100 \mathrm{~mL})$, and the mixture was heated to reflux for $4 \mathrm{~h}$. After cooling to $25^{\circ} \mathrm{C}$, the mixture was extracted with $\mathrm{CH}_{2} \mathrm{Cl}_{2}$ and $\mathrm{H}_{2} \mathrm{O}$. The organic layers were collected and concentrated under vacuum. The residue was purified by column chromatography using hexane/ $\mathrm{CH}_{2} \mathrm{Cl}_{2}(30: 1)$ as eluent to yield 2 as a white solid $(2.56 \mathrm{~g}, 92.4 \%) .{ }^{1} \mathrm{H}$ $\operatorname{NMR}\left(400 \mathrm{MHz}, \mathrm{CDCl}_{3}, 25{ }^{\circ} \mathrm{C}\right) \delta(\mathrm{ppm}):$ 7.15-7.06 (m, 9H), 7.06-6.98 (m, 6H), $6.90(\mathrm{~s}, 4 \mathrm{H}), 2.25(\mathrm{~s}, 3 \mathrm{H}) \cdot{ }^{13} \mathrm{C}$ $\operatorname{NMR}\left(100 \mathrm{MHz}, \mathrm{CDCl} 3,25^{\circ} \mathrm{C}\right) \delta(\mathrm{ppm}): 143.99,141.16,140.94,140.78,140.51,136.09,131.40,131.36,131.27$, $128.99,128.51,128.43,127.70,127.65,126.37,126.33,126.12,21.24$.

\section{Synthesis of compound 3}

Compound 2 (2.56 g, $7.39 \mathrm{mmol})$, N-bromosuccinimide ( $1.57 \mathrm{~g}, 8.87 \mathrm{mmol})$, and benzoyl peroxide ( $36 \mathrm{mg}, 0.15$ mmol) were dissolved in chloroform $(80 \mathrm{~mL})$ and refluxed for $18 \mathrm{~h}$. The resulting mixture was concentrated under vacuum. The residue was purified by column chromatography using hexane $/ \mathrm{CH}_{2} \mathrm{Cl}_{2}(4: 1)$ as eluent to yield compound 3 as a white solid $(0.61 \mathrm{~g}, 19.5 \%) .{ }^{1} \mathrm{H}$ NMR $\left(400 \mathrm{MHz}, \mathrm{CDCl}_{3}, 25^{\circ} \mathrm{C}\right) \delta(\mathrm{ppm}): 7.15-7.06(\mathrm{~m}, 11 \mathrm{H})$, 7.05-6.96 (m, 8H), 4.41(s, 2H). ${ }^{13} \mathrm{C}$ NMR $\left(100 \mathrm{MHz}, \mathrm{CDCl}_{3}, 25{ }^{\circ} \mathrm{C}\right) \delta(\mathrm{ppm}): 143.98,143.56,143.49,143.43$, 
$141.55,140.23,135.71,131.68,131.63,131.34,131.29,128.42,127.92,127.76,127.73,127.66,126.61,126.55$, $126.53,33.64$.

\section{Synthesis of TPE-PiPrOx-R6G}

A Schlenk flask was degassed under high vacuum and backfilled with $\mathrm{N}_{2}$; this process was repeated three times. A solution of initiator $3(0.5 \mathrm{~g}, 1.17 \mathrm{mmol})$ in $\mathrm{MeCN}(5 \mathrm{~mL})$ was placed in the Schlenk flask, and then a solution of 2-isopropyl-2-oxazoline (iPrOx) $(4.63 \mathrm{~g}, 40.95 \mathrm{mmol})$ was added, where the ratio of the initiator to the monomer was 1:35. The mixture was stirred at $40{ }^{\circ} \mathrm{C}$ under a $\mathrm{N}_{2}$ atmosphere for $4 \mathrm{~d}$. The reaction was monitored by analytical SEC and MALDI-TOF-MS. After confirming that the target molecular weight was reached, a solution of Rhodamine $6 \mathrm{G}(0.67 \mathrm{~g}, 1.4 \mathrm{mmol})$ in $\mathrm{MeOH}(1 \mathrm{~mL})$ was added as terminator to the reaction mixture, which was further stirred at $70^{\circ} \mathrm{C}$ for $48 \mathrm{~h}$. The mixture was poured into DCM and washed with brine. The organic layer was dried over anhydrous $\mathrm{MgSO}_{4}$ and concentrated under reduced pressure. The residue was purified by recycling preparative $\mathrm{SEC}$ using $\mathrm{CHCl}_{3}$ as eluent to afford TPE-POx-R6G as a pink powder $(1.15 \mathrm{~g}, 23.3 \%) .{ }^{1} \mathrm{H}$ NMR (400 MHz, $\left.\mathrm{CDCl}_{3}, 25^{\circ} \mathrm{C}\right) \delta(\mathrm{ppm}):$ 7.30-6.92 (m, 27H; Ar-H of Rhodamine 6G and TPE), 4.5-4.05 (m, 4H; $-\mathrm{OCH}_{2}$ - of Rhodamine 6G and TPE- $\mathrm{CH}_{2}$ - of TPE), 3.45 (br, $132 \mathrm{H},-\mathrm{CH}_{2}-\mathrm{CH}_{2}$ - of the polymer backbone), 2.902.64 (br; - $\mathrm{CH}-$ of the polymer side chain), 2.41-2.36 (m, $6 \mathrm{H} ;-\mathrm{CH}_{3}$ of Rhodamine $\left.6 \mathrm{G}\right), 2.37$ (s, 3H; $-\mathrm{CH}_{3}$ of Rhodamine 6G), 2.15 (s, 3H; - $\mathrm{CH}_{3}$ of Rhodamine 6G), 1.49 (m, 2H, $-\mathrm{NCH}_{2}$ - of Rhodamine 6G), 1.10 (br, 210H, $-\mathrm{CH}_{3}$ of the polymer side chain, and $-\mathrm{CH}_{3}$ of Rhodamine $\left.6 \mathrm{G}\right) \cdot{ }^{13} \mathrm{C}$ NMR $\left(100 \mathrm{MHz}, \mathrm{CDCl}_{3}, 25{ }^{\circ} \mathrm{C}\right) \delta(\mathrm{ppm})$ : $178.02,177.93,177.60,143.43,143.24,131.86,131.72,131.12,127.56,126.46,125.71,125.65,125.42,47.42$, $47.05,46.59,45.79,43.92,35.21,33.80,30.17,29.79,20.09,19.82,19.63,18.93$.

\section{Synthesis of TPE-PiPrOx}

A Schlenk flask was degassed under high vacuum and backfilled with $\mathrm{N}_{2}$; this process was repeated three times. A solution of initiator $3(0.5 \mathrm{~g}, 1.17 \mathrm{mmol})$ in $\mathrm{MeCN}(10 \mathrm{~mL})$ was placed in the Schlenk flask, and then $\boldsymbol{i}$ PrOx (4.63 g, $40.95 \mathrm{mmol}$ ) was added, where the ratio of the initiator to the monomer was 1:35. The mixture was stirred at $40{ }^{\circ} \mathrm{C}$ under a $\mathrm{N}_{2}$ atmosphere for $4 \mathrm{~d}$. The reaction was monitored by analytical SEC and MALDI-TOF-MS. After confirming that the target molecular weight was reached, a solution of sodium azide $(0.21 \mathrm{~g}, 3.18 \mathrm{mmol})$ in $\mathrm{H}_{2} \mathrm{O}(1 \mathrm{~mL})$ was added as terminator to the reaction mixture, which was further stirred at $70{ }^{\circ} \mathrm{C}$ for $72 \mathrm{~h}$. The mixture was poured into DCM and washed with brine. The organic layer was dried over anhydrous $\mathrm{MgSO}_{4}$ and 
concentrated under vacuum. The residue was purified by recycling preparative SEC using $\mathrm{CHCl}_{3}$ as eluent to afford TPE-PiPOx as an ivory powder $(3.5 \mathrm{~g}, 66 \%) .{ }^{1} \mathrm{H}$ NMR $\left(400 \mathrm{MHz}, \mathrm{CDCl}_{3}, 25^{\circ} \mathrm{C}\right) \delta(\mathrm{ppm}): 7.52-6.86(\mathrm{~m}$, $19 \mathrm{H}, \mathrm{Ar}-\mathrm{H}$ of TPE), 4.51 (d, $2 \mathrm{H}, \mathrm{TPE}-\mathrm{CH}_{2}-\mathrm{N}$ of the polymer backbone), 3.45 (br, $-\mathrm{CH}_{2}-\mathrm{CH}_{2}$ - of the polymer backbone), 2.89-2.67 (br, - $\mathrm{CH}$ - of the polymer side chain), 2.15 (d, $2 \mathrm{H},-\mathrm{CH}_{2}-\mathrm{N}_{3}$ of the polymer backbone), 1.20 (br, $-\mathrm{CH}_{3}$ of the polymer side chain). ${ }^{13} \mathrm{C} \mathrm{NMR}\left(100 \mathrm{MHz}, \mathrm{CDCl}_{3}, 25^{\circ} \mathrm{C}\right) \delta(\mathrm{ppm}): 178.80,177.99,177.66,143.52$, $143.44,143.26,132.02,131.19,127.63,126.58,126.41,125.79,47.59,47.14,46.63,45.88,43.98,30.24,29.98$, $29.85,19.88,19.69$

\section{Synthesis of R6G-PiPrOx}

A Schlenk flask was degassed under high vacuum and backfilled with $\mathrm{N}_{2}$; this process was repeated three times. A solution of the initiator methyl $p$-toluenesulfonate $(0.27 \mathrm{~g}, 1.47 \mathrm{mmol})$ in $\mathrm{MeCN}(10 \mathrm{~mL})$ was placed in the above Schlenk flask, and then $\boldsymbol{i}$ PrOx $(5.82 \mathrm{~g}, 51.5 \mathrm{mmol})$ was added, where the ratio of the initiator to the monomer was 1:35. The mixture was stirred at $40{ }^{\circ} \mathrm{C}$ under a $\mathrm{N}_{2}$ atmosphere for $4 \mathrm{~d}$. The reaction was monitored by analytical SEC and MALDI-TOF-MS. After confirming that the target molecular weight was reached, a solution of Rhodamine $6 \mathrm{G}(0.67 \mathrm{~g}, 1.4 \mathrm{mmol})$ in $\mathrm{MeOH}(1 \mathrm{~mL})$ was added as terminator to the reaction mixture, which was further stirred at $70{ }^{\circ} \mathrm{C}$ for $48 \mathrm{~h}$. The mixture was poured into DCM and washed with brine. The organic layer was dried over anhydrous $\mathrm{MgSO}_{4}$ and concentrated under vacuum. The residue was purified by recycling preparative SEC using $\mathrm{CHCl}_{3}$ to afford R6G-PiPrOx as a pink powder $(3.90 \mathrm{~g}, 35.5 \%) .{ }^{1} \mathrm{H}$ NMR $(400 \mathrm{MHz}$, $\left.\mathrm{CDCl}_{3}, 25^{\circ} \mathrm{C}\right) \delta(\mathrm{ppm}): 7.66-6.76(\mathrm{~m}, 9 \mathrm{H}, \mathrm{Ar}-\mathrm{H}$ of Rhodamine $6 \mathrm{G}), 4.14$ (s, $4 \mathrm{H},-\mathrm{NCH}_{2}$ - of Rhodamine $\left.6 \mathrm{G}\right), 3.44$ (br, $-\mathrm{CH}_{2}-\mathrm{CH}_{2}$ - of the polymer backbone), 3.10 (s, 3H; $-\mathrm{CH}_{3}$ - of the terminal), 2.90-2.67 (br, - $\mathrm{CH}$ of the polymer side chain), 1.70 (br, $-\mathrm{CH}_{3}$ of the polymer side chain). ${ }^{13} \mathrm{C} \mathrm{NMR}\left(100 \mathrm{MHz}, \mathrm{CDCl}_{3}, 25{ }^{\circ} \mathrm{C}\right) \delta(\mathrm{ppm}): 177.90$, $161.64,160.07,154.17,153.54,149.84,145.30,144.90,134.99,129.27,128.94,128.33,124.81,120.19,112.37$, $94.48,62.30,61.76,57.92,53.41,46.59,43.87,35.24,33.82,30.16,21.16,19.61,18.28,16.79,13.57,8.64$. 


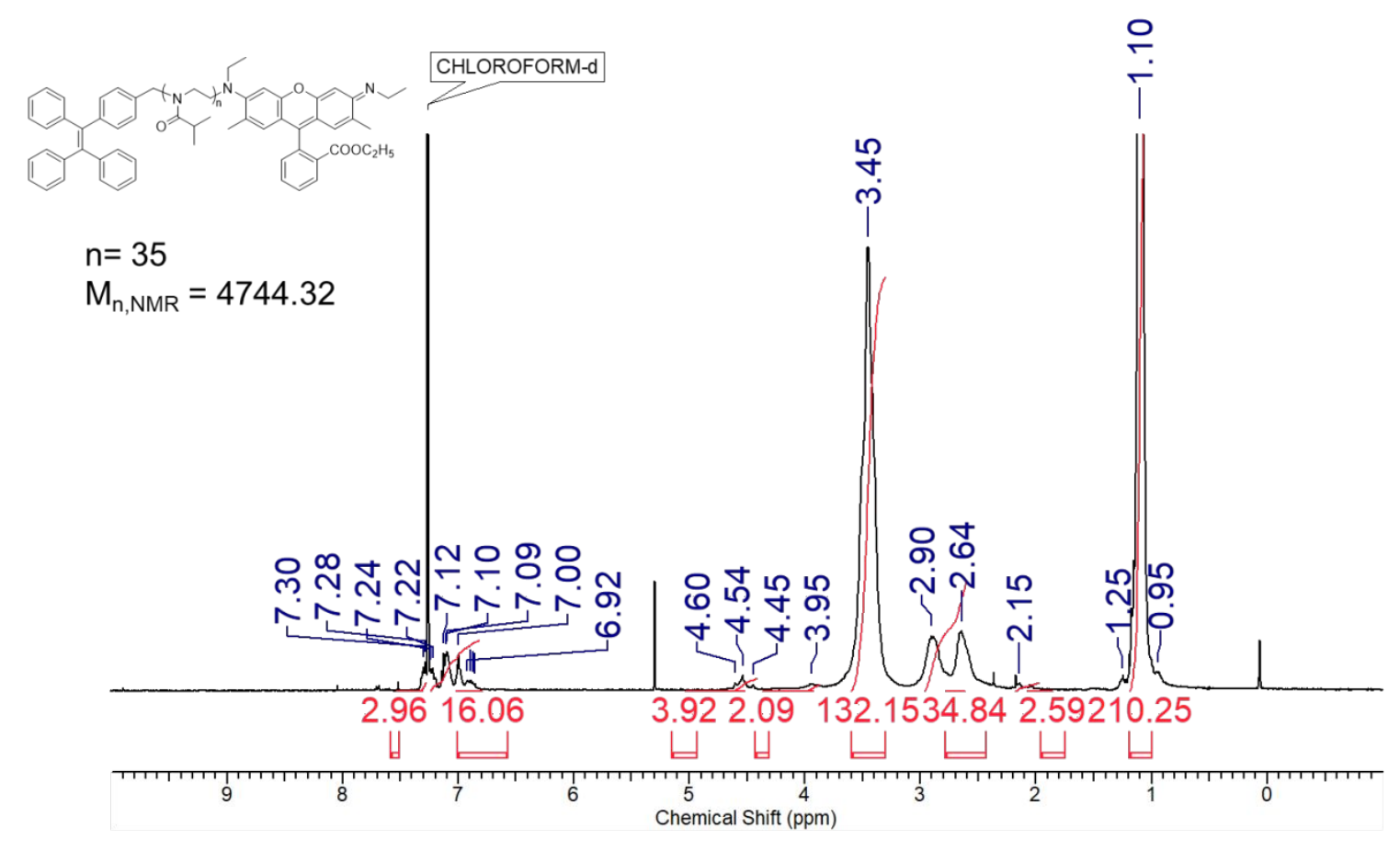

Figure S1. ${ }^{1} \mathrm{H}$ NMR spectrum of TPE-PiPrOx-Rh.<smiles>BrCc1ccc(C(=C(c2ccccc2)c2ccccc2)c2ccccc2)cc1</smiles>

3

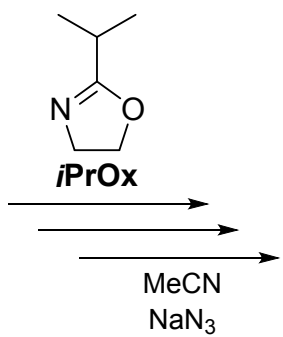

$\mathrm{aN}_{3}$<smiles>CC(C)C(=O)N(C)CCc1ccc(C(=C(c2ccccc2)c2ccccc2)c2ccccc2)cc1</smiles>

TPE-PiPrOx<smiles>COS(=O)(=O)c1ccc(C)cc1</smiles>

Methyl $p$-toluenesulfonate<smiles>CCN=c1cc2oc3cc(N(C)CC)c(C)cc3c(-c3ccccc3C(=O)OCC)c-2cc1C</smiles>

R6G-PiPrOx

Scheme S1. Synthesis of TPE-PiPrOx and R6G-PiPrOx. 


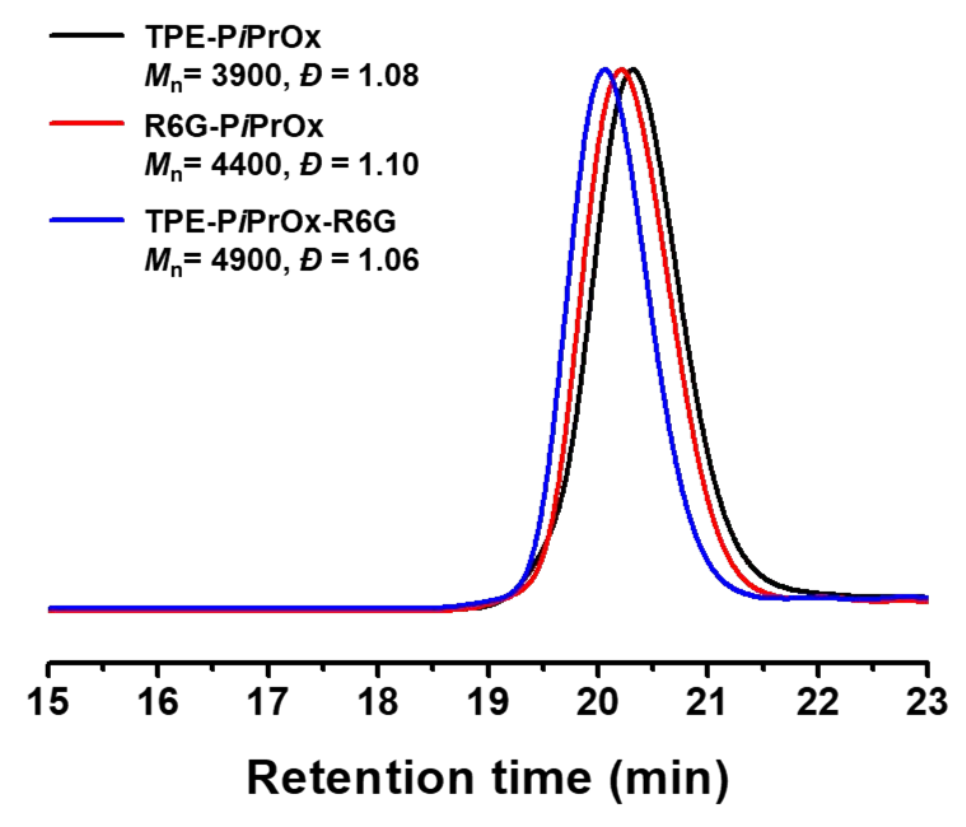

Figure S2. SEC trace of TPE-PiPrOx, R6G-PiPrOx and TPE-PiPrOx-R6G.

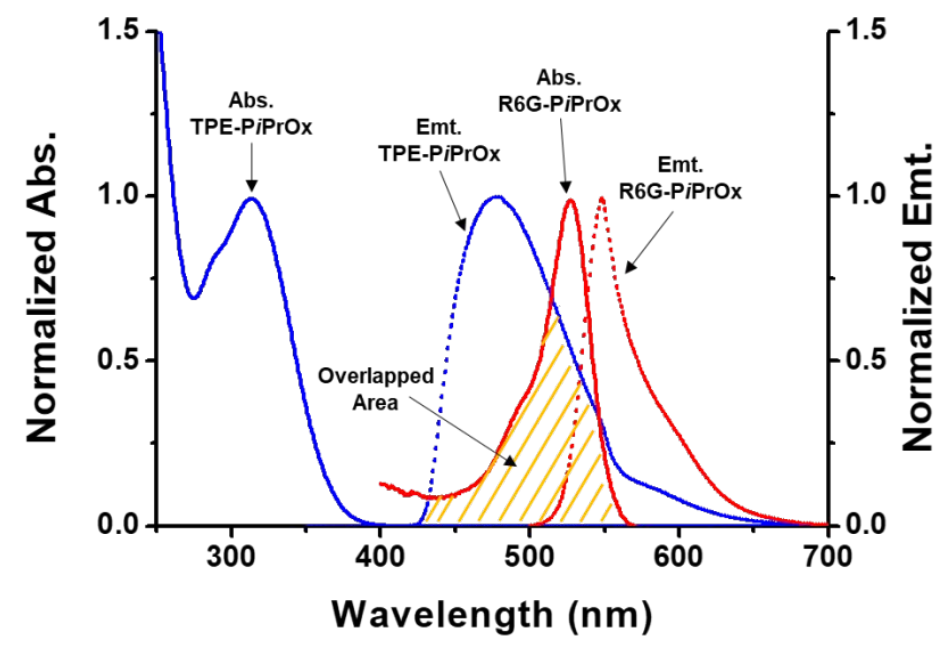

Figure S3. Absorption and emission spectra of TPE-PiPrOx and R6G-PiPrOx in $\mathrm{H}_{2} \mathrm{O}$. In the emission spectra, TPE-PiPrOx and R6G-PiPrOx were excited at 310 and 480 nm, respectively. 


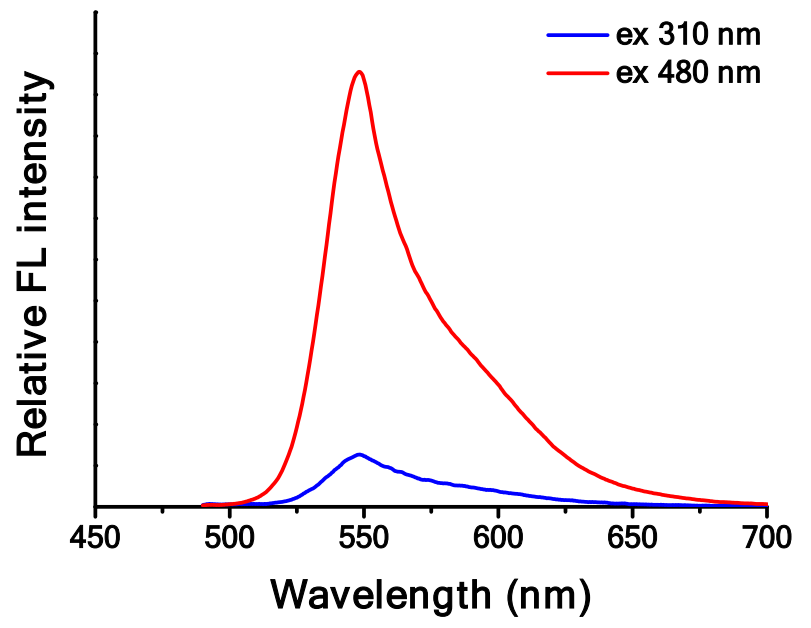

Figure S4. Emission spectra of R6G-PiPrOx in water when excited at 310 and $480 \mathrm{~nm}$.

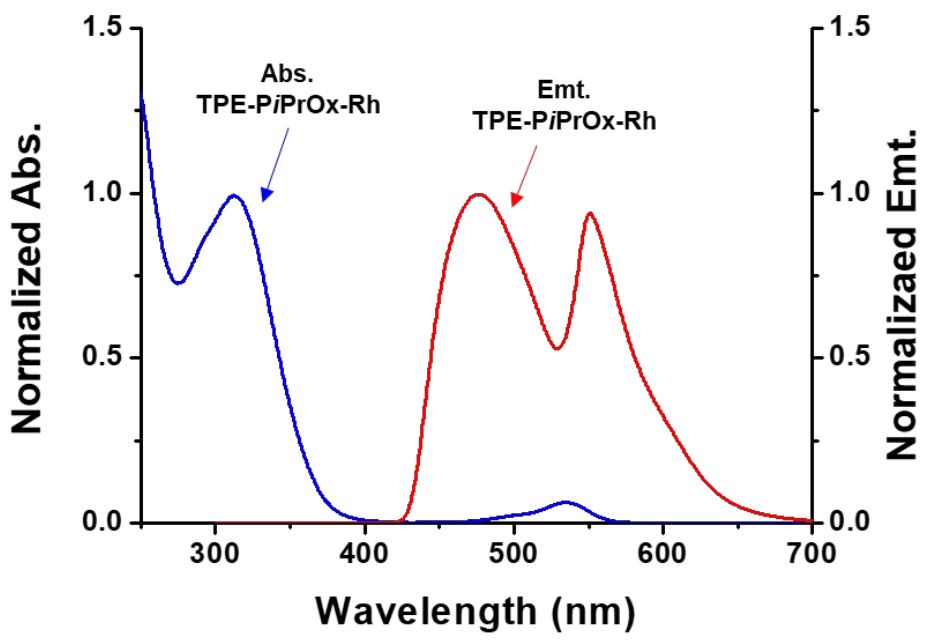

Figure S5. Absorption and emission spectra of TPE-PiPrOx-R6G in water, excited at $310 \mathrm{~nm}$ for the emission spectrum. 
(a)

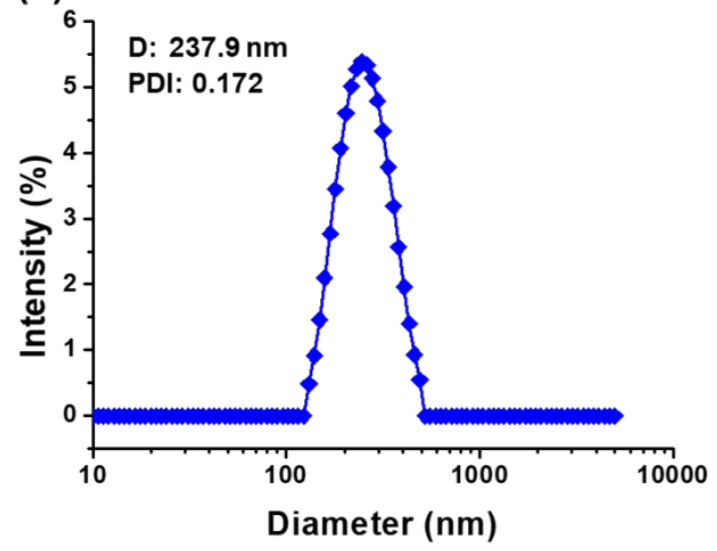

(b)

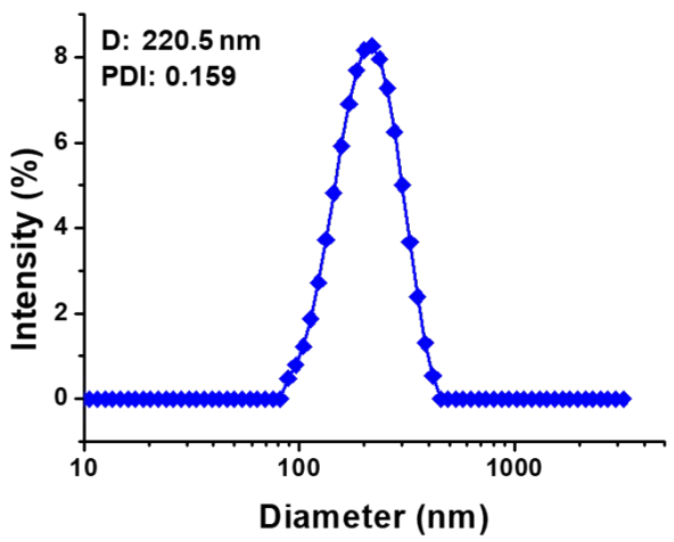

Figure S6. Size distributions as observed by DLS with a $1.00 \mathrm{~g} \cdot \mathrm{L}^{-1}$ solution of (a) TPE-PiPrOx and (b) R6GPiPrOx in water.

(a)

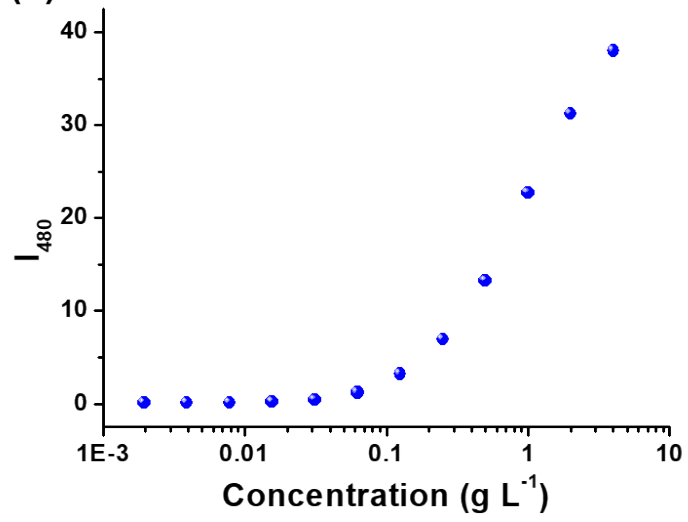

(b)

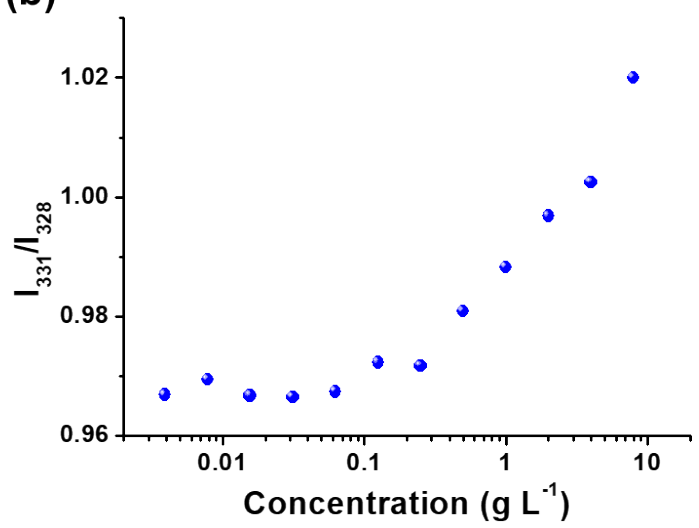

Figure S7. CMC measurements of TPE-PiPrOx and R6G-PiPrOx. (a) Plot of the FL emission intensity at 480 nm of TPE-PiPrOx at different concentrations $\left(2.00 \times 10^{-3}-4.00 \mathrm{~g} \cdot \mathrm{L}^{-1}\right)$ in water. (b) Plot of the intensity ratio $\left(I_{331} / I_{328}\right)$ obtained from the FL excitation spectra of pyrene $\left(2.00 \times 10^{-6} \mathrm{M}\right)$ with R6G-PiPrOx at different concentrations $\left(4.00 \times 10^{-3}-8.00 \mathrm{~g} \cdot \mathrm{L}^{-1}\right)$ in water. 


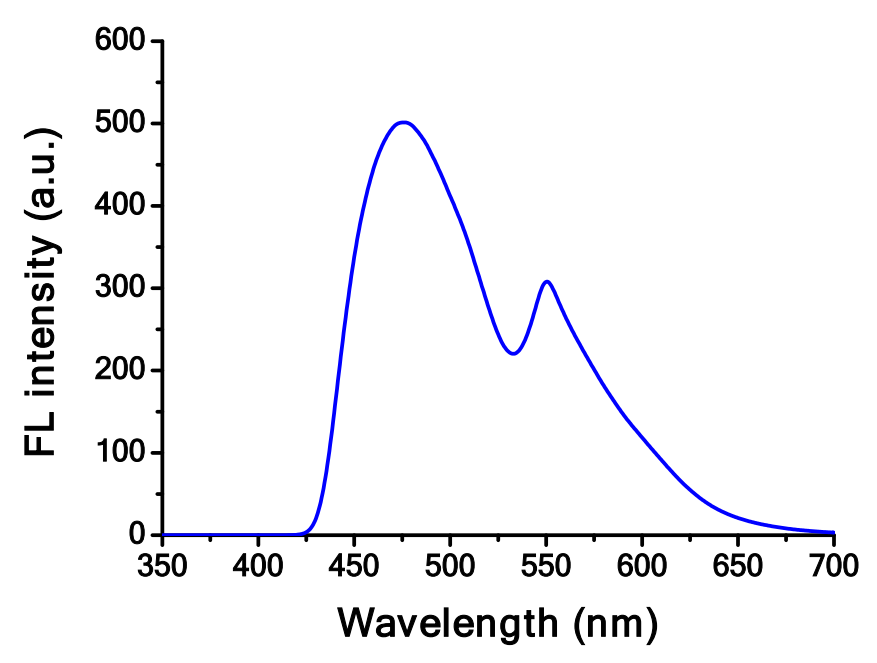

Figure S8. FL emission spectrum of a 1:1 mixture solution $\left(2.00 \mathrm{~g} \cdot \mathrm{L}^{-1}\right)$ of TPE-PiPrOx and R6G-PiPrOx in water excited at $310 \mathrm{~nm}$.

Table S1. Fluorescence quantum yields of TPE-PiPrOx-R6G $\left(1 \mathrm{~g} \cdot \mathrm{L}^{-1}\right)$ with/without $\gamma$-CD $(10 \mathrm{mM})$ in water at different temperature.

\begin{tabular}{|c|c|c|c|c|c|c|c|c|c|c|c|c|}
\hline \multirow{2}{*}{ Sample } & \multicolumn{12}{|c|}{$\Phi_{F}{ }^{a}(\%)$ at temperature $\left({ }^{\circ} \mathrm{C}\right)$} \\
\hline & 15 & 20 & 25 & 30 & 35 & 40 & 45 & 50 & 55 & 60 & 65 & 70 \\
\hline TPE-PiPrOx-R6G & 33.3 & 30.5 & 28.1 & 18.4 & 9.8 & 8.8 & 8.0 & 6.2 & 4.6 & 3.9 & 3.7 & 4.1 \\
\hline $\begin{array}{l}\text { TPE-PiPrOx-R6G } \\
+\gamma \text {-CD }\end{array}$ & 2.1 & 1.9 & 1.8 & 1.9 & 3.5 & 6.0 & 9.2 & 9.6 & 8.4 & 6.8 & 5.9 & 5.3 \\
\hline
\end{tabular}




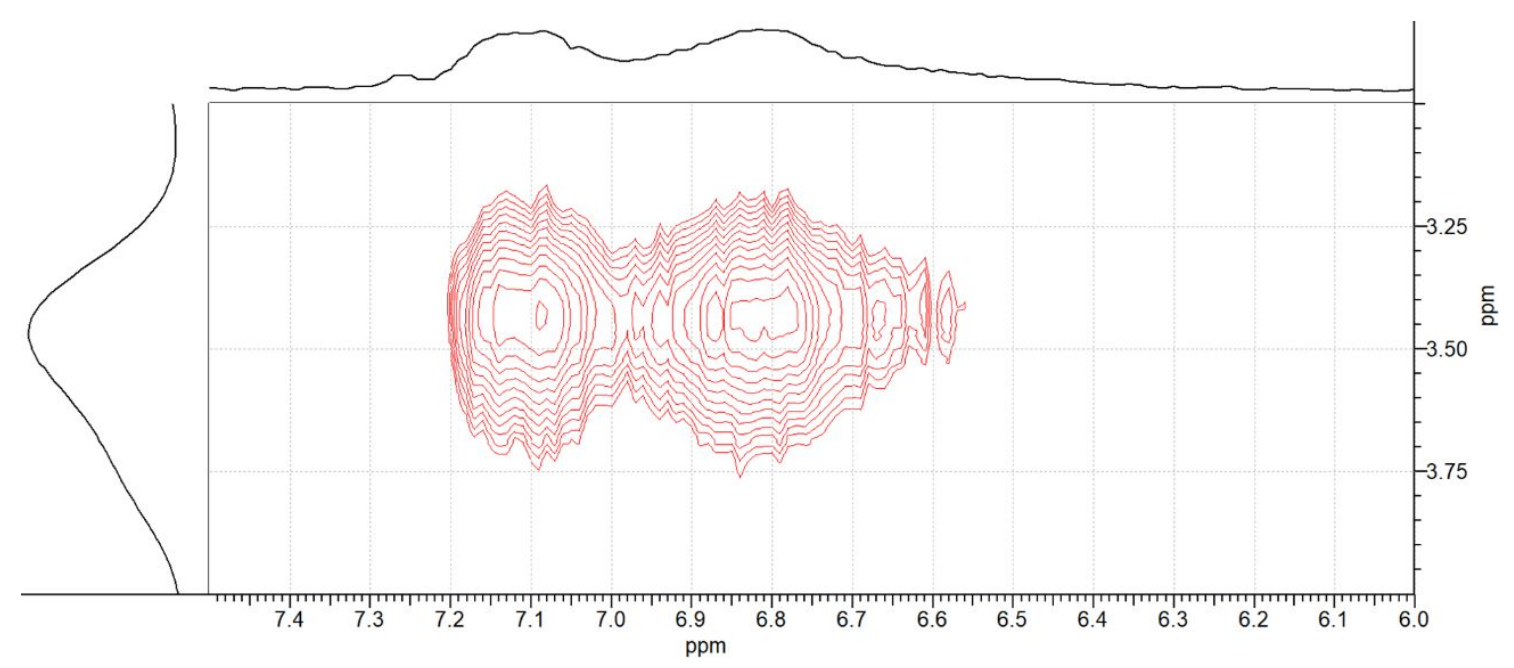

Figure S9. 2D NOESY ${ }^{1} \mathrm{H}$ NMR spectrum of TPE-PiPrOx-R6G $\left(5.00 \mathrm{~g} \cdot \mathrm{L}^{-1}\right)$ and $\gamma$-CD $(2.00 \mathrm{mM})$ in $\mathrm{D}_{2} \mathrm{O}$.

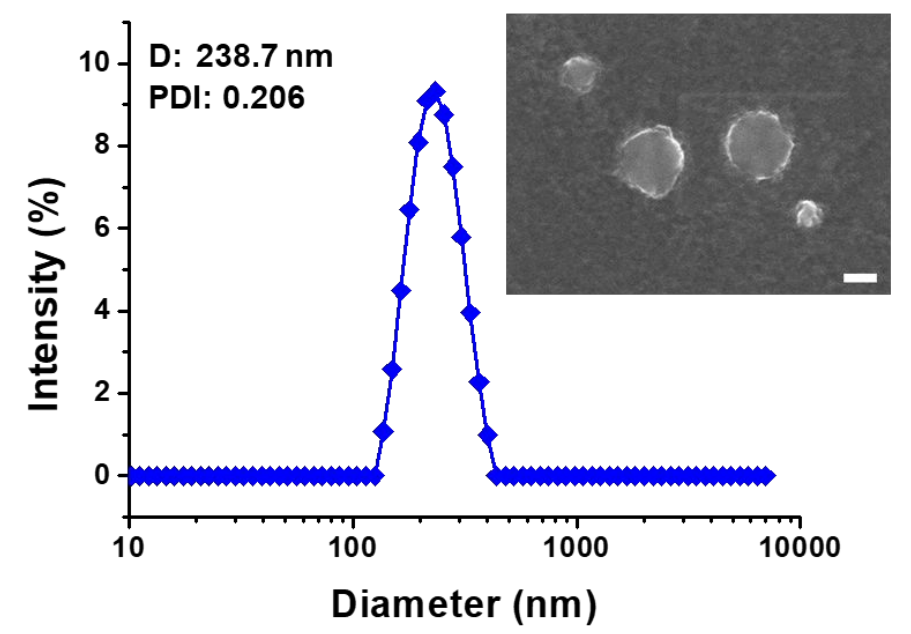

Figure S10. Size distribution as observed by DLS of a mixture of TPE-PiPrOx-R6G $\left(1.00 \mathrm{~g} \cdot \mathrm{L}^{-1}\right)$ and $\gamma$-CD $(10$ $\mathrm{mM}$ ) in water (inset: SEM image of the obtained micelles of the complex between TPE-PiPrOx-R6G and $\gamma$-CD. Scale bar $=200 \mathrm{~nm})$. 


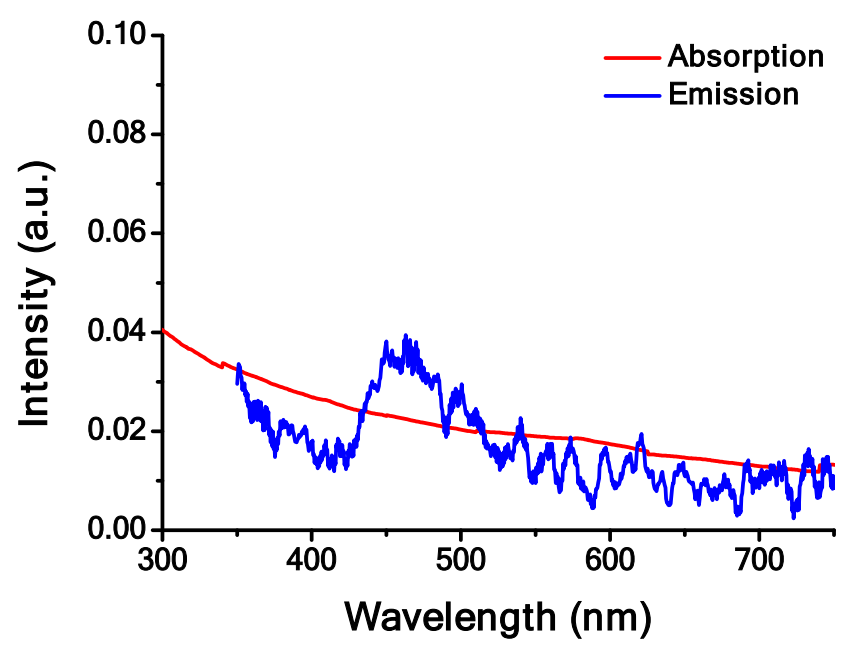

Figure S11. Absorption and emission spectra of $\gamma$-CD $(10 \mathrm{mM})$ in water, excited at $310 \mathrm{~nm}$ for the emission spectrum. 